\title{
Stability of the mRNA encoding some pancreatic hydrolases is modulated by dietary protein intake in the rat
}

\author{
SUZANNE CARREIRA, CHRISTIAN FUERI, JEAN-CLAUDE CHAIX \\ AND ANTOINE PUIGSERVER* \\ Laboratoire de Biochimie et Biologie de la Nutrition, CNRS-URA 1820, \\ Faculté des Sciences et Techniques de St-Jérôme, Service 342, \\ 13397 Marseille Cedex 20, France
}

(Received 6 June 1996 - Revised 2 January 1997 - Accepted 11 April 1997)

\begin{abstract}
Wistar rats fed on either a high-protein or a protein-free diet were examined to determine their pancreatic hydrolase mRNA stabilities in comparison with those of control animals receiving a standard diet. Actinomycin $D$ was used to inhibit transcription and, after isolating the pancreatic RNA, the specific messengers were quantified by performing dot-blot hybridization with cDNA probes. In the rats fed on a high-protein diet, only the half-lives of anionic trypsinogen I and elastase I (EC 3.4.21.36) were affected. Interestingly, when rats were fed on the protein-free diet, most of the hydrolase mRNA half-lives showed changes, except that corresponding to lipase. In these rats, the half-life values of the mRNA coding for anionic trypsinogen I, chymotrypsinogen and procarboxypeptidase $B$ increased, in sharp contrast with those of the amylase and elastase I mRNA, which decreased. These results strongly suggest that the mechanism whereby the biosynthesis of pancreatic hydrolases is regulated, depending on the presence or absence of proteins in the diet, is not unique and provide evidence that the stability of mRNA encoding most, if not all, the hydrolases in pancreatic cells is modulated by the dietary protein content.
\end{abstract}

Pancreas: Dietary protein: mRNA: Rat

Rat pancreatic juice contains both low- and neutral-isoelectric-point secretory anionic proteins, i.e. procarboxypeptidases $\mathrm{A}$ and $\mathrm{B}$ ( $E C$ 3.4.17.1), chymotrypsinogen 1 ( $E C$ 3.4.21.1), proelastase 1 (EC 3.4.21.36), trypsinogens 1 and $2(E C 3.4 .21 .4)$ and lipase $(E C$ 3.1.1.3), as well as high-isoelectric-point cationic enzymes and zymogens, i.e. ribonuclease (EC 3.1.27.5), amylase (EC 3.2.1.1), chymotrypsinogen 2, proelastase 2 and trypsinogen 3 (Scheele, 1986). It has been established for a long time in rats, dogs and several other species that the pancreatic secretion is modulated by the chemical composition of the diet (Grossman et al. 1943; Ben Abdeljlil \& Desnuelle, 1964; Reboud et al. 1966). Pancreatic adaptation to nutritional substrates has been thoroughly documented and is known to involve changes in both the tissue level and the rate of biosynthesis of specific enzymes. The respective levels of the main digestive enzymes, i.e. those of serine proteases, amylase and lipase in the pancreas and pancreatic secretion (Gross et al. 1943; Behrman \& Kare, 1969), have been found to vary in direct proportion to the dietary levels of their corresponding substrates, protein, carbohydrate and fat (Reboud et al. 1962; Gidez, 1973). Pancreatic adaptation involves changes in the rates of synthesis of the secretory proteins (Reboud et al. 1966; Dagorn \& Lahaie, 1981; Wicker \& Puigserver, 1987) as well as in the specific mRNA levels (Giorgi et al. 1985; Wicker et al. 1984, 1988). 
When high-protein diets (640-810 g casein $/ \mathrm{kg}$ ) are used and compared with control diets, the increase in the serine protease content of the pancreatic tissue is due to the enhancement of both their rates of synthesis and their mRNA levels (Schick et al. 1984; Wicker et al. 1984). Under these dietary conditions, the amylase content, synthesis and mRNA level decreased, while the lipase content, synthesis and mRNA level remained unchanged. These findings clearly indicated that changes in the mRNA levels mediated the observed changes in protein synthesis in response to induced changes in the dietary carbohydrate and protein levels. Parallel changes in both the mRNA levels and the rates of protein synthesis after feeding on a high-protein diet strongly suggested that the enzymic adaptation might either result directly from the presence of some nutrient in the diet or be indirectly due to the action of some hormone (Dagorn \& Lahaie, 1981) and involve the regulation of gene expression at the transcriptional level, and/or result from some change in the mRNA stability rather than from some translational control.

When a protein-free carbohydrate-rich diet is ingested by rats instead of a normalprotein diet, amylase and the group of protease zymogens are synthesized in high amounts, which are obviously not in direct proportion, but rather reversely proportional, to their nutritional substrates in the diet (Schick et al. 1984). It is noteworthy that the increase in the relative rate of synthesis of serine proteases was observed only in the case of anionic isozymes, since protein deprivation increased the specific mRNA levels of the serine proteases, except that of the elastase isoforms (Dakka et al. 1990). The decrease in the content and rate of synthesis of most enzymes during protein deprivation, in addition to the paradoxical increase in the anionic protease isozyme levels, are usually thought to possibly constitute protective mechanisms ensuring the availability of the proteases necessary to digest any protein consumed (Schick et al. 1984). The adaptation of secretory pancreatic protein synthesis to a protein-free diet seems to involve both transcriptional and translational controls (Dakka et al. 1988), and possibly an additional control at the level of the mRNA stability.

Whatever the protein content of the diet, the mechanism whereby dietary macronutrients affect the expression of specific pancreatic enzymes may occur at the level of gene transcription and subsequent mRNA processing, extranuclear transport, translation and cytoplasmic stability. The pancreatic response might either be direct or proceed via a single or several hormones.

In the present study, the stability of the mRNA coding for pancreatic hydrolases was determined in rats fed on high-protein and protein-free diets as compared with a control diet. After injecting the transcription inhibitor actinomycin $\mathrm{D}$, the mRNA levels were measured in the pancreas of rats fed for $10 \mathrm{~d}$ on the experimental diets. The results reported here provide evidence that changes in the stability of some mRNA may completely account for the observed changes in the corresponding secretory protein levels in response to nutritional manipulations.

\section{EXPERIMENTAL METHODS}

\section{Animals and diets}

The detailed composition of the isoenergetic standard ( $230 \mathrm{~g}$ casein $/ \mathrm{kg})$, protein-free $(0 \mathrm{~g}$ casein $/ \mathrm{kg}$ ) and high-protein $(640 \mathrm{~g}$ casein $/ \mathrm{kg}$ ) diets is given in Table 1 . Male Wistar rats weighing 180-200 g were purchased from Iffa-Credo (L'Arbesle, France). Animals were weighed and housed individually in a temperature-controlled room $\left(20^{\circ}\right)$ with lights on from 08.00 hours to 20.00 hours. Animals were randomly assigned to three groups of fifteen animals each, which were given either standard or experimental diets for $10 \mathrm{~d}$. All 
three isoenergetic diets were purchased from Usine d'Alimentation Rationnelle (Essone, France) and all the animals had free access to food and water. After being weighed, each dietary group of fifteen animals was subdivided into three 'time groups' of five animals each and intraperitoneally injected with actinomycin $D$ at $2 \mathrm{mg} / \mathrm{kg}$ body weight from a stock solution containing $2 \mathrm{mg}$ transcription inhibitor $/ \mathrm{ml}$ saline $(9 \mathrm{~g} \mathrm{NaCl} / 1)$. The rats were killed by cervical dislocation at two different times $(3 \mathrm{~h}$ and $6 \mathrm{~h})$ after the actinomycin $\mathrm{D}$ injection and the control animals (zero time) of each dietary group were killed immediately after the administration of actinomycin $\mathrm{D}$.

\section{Isolation of pancreatic RNA}

Once each pancreatic gland had been rapidly removed by surgical excision, total pancreatic RNA was prepared by high-speed homogenization of the tissue, using the guanidine isothiocyanate procedure (Chomczynski \& Sacchi, 1987) with slight modifications. Briefly, about $1 \mathrm{~g}$ tissue in $10 \mathrm{ml} 50 \mathrm{mM}$ Tris-hydrochloride buffer $\mathrm{pH}$ 7.5), containing $5 \mathrm{M}$-guanidinium thiocyanate, $25 \mathrm{mM}$-EDTA, $\beta$-mercaptoethanol $(8 \mathrm{ml} / 1)$ and sarcosyl $(5 \mathrm{ml} / 1)$, was homogenized three times for $10 \mathrm{~s}$ at full speed in a Polytron homogenizer. After subsequent phenol-chloroform $(1: 1, \mathrm{v} / \mathrm{v})$ and chloroform-isoamyl alcohol $(1: 24, \mathrm{v} / \mathrm{v})$ extraction of the total RNA, the soluble material was precipitated with isopropanol $\left(0.6 \mathrm{vol}\right.$.) at $-70^{\circ}$ and the preparation was sedimented at $10000 \mathrm{~g}$ for $15 \mathrm{~min}$ at $4^{\circ}$ in a Sorval SS-34 super-speed rotor (Dupont de Nemours, Les Ullis, France), and finally redissolved in $5 \mathrm{ml} 4 \mathrm{M}$-guanidinium thiocyanate solution. The pellet resulting from ethanol $(2.5 \mathrm{vol})$ and $0.3 \mathrm{M}$-sodium acetate precipitation was sedimented as indicated previously, washed twice with ethanol $(700 \mathrm{ml} / \mathrm{l})$, air-dried and finally dissolved in $10 \mathrm{mM}$-Tris-hydrochloride $\mathrm{pH} 8$ and $1 \mathrm{mM}$-EDTA at $\mathrm{pH} 8$ containing $1 \mathrm{mM}$-dithiothreitol and 60 units of RNAsin (Boehringer-Mannheim, Mannheim, Germany).

\section{Northern-blot analysis}

Qualitative analysis of each sample of total RNA was performed by Northern blot. Each RNA sample (10 and $30 \mu \mathrm{g}$ ) was denatured, subjected to electrophoresis through a $1.2 \%$ agarose gel in the presence of formaldehyde (Sambrook et al. 1989) and transferred to a nylon membrane (Hybond N; Amersham, Les Ullis, France) using a vacuum blotter (trans$\mathrm{Vac}^{\mathrm{TM}}$ TE 80; Hoefer Scientific Instruments, San Francisco, CA, USA). The uniformity of

Table 1. Diet composition $(\mathrm{g} / \mathrm{kg})$

\begin{tabular}{lccc}
\hline \hline Diet ... & Protein-free & Standard & High-protein \\
\hline Casein & 0 & 230 & 640 \\
Maize starch & 300 & 200 & 64 \\
Dextrose & 510 & 380 & 106 \\
Colza oil* & 10 & 10 & 10 \\
Maize oil & 10 & 10 & 10 \\
Lard & 30 & 30 & 30 \\
Mineral mix 205B $\dagger$ & 10 & 10 & 10 \\
Vitamin mix 200† & 70 & 70 & 70 \\
Cellulose & 60 & 60 & 60 \\
\hline
\end{tabular}

* Nouvelles Huileries et Raffineries Massilia, Marseille, France.

$\dagger$ Usine d'Alimentation Rationelle, Villemoisson-sur-Orge, France. 
RNA transfer to the nylon membrane was verified by using the methylene blue staining method. After transfer, the blots were soaked for $15 \mathrm{~min}$ in an acetic acid solution $(50 \mathrm{ml} / \mathrm{l})$ followed by $10 \mathrm{~min}$ in a $0.5 \mathrm{M}$-sodium acetate with methylene blue $(0.4 \mathrm{~g} / \mathrm{l})$ solution (Sambrook et al. 1989). The integrity of the RNA was evaluated from the appearance of the $28 \mathrm{~S}$ and $18 \mathrm{~S}$ rRNA on the agarose gel after ethidium bromide staining. To control for loading differences, densitometry was performed on Polaroid ${ }^{\circledR}$ photographs of the ethidium bromide-stained gels as described by Bonini \& Hofmann (1991).

\section{Quantification of specific $m R N A$}

The concentration of each specific mRNA was determined by performing dot-blot hybridization analysis. The appropriate amount of each total RNA (about $80 \mu \mathrm{g}$ ) was dissolved in $180 \mu \mathrm{l}$ distilled water, mixed with $420 \mu \mathrm{l}$ of a solution containing $3.7 \mathrm{M}$ formaldehyde, $14 \times \mathrm{SSPE}\left(1 \times \mathrm{SSPE}: 150 \mathrm{mM}-\mathrm{NaCl}, 10 \mathrm{mM}-\mathrm{NaH}_{2} \mathrm{PO}_{4}, 1 \mathrm{mM}-\mathrm{EDTA}\right.$ at $\mathrm{pH} 7.4$ ), and heated at $65^{\circ}$ for $15 \mathrm{~min}$. The resulting denatured RNA samples were spotted onto nitrocellulose filters in eight sequential dilutions using the manifold apparatus (Minifold I; Schleicher and Schüll, Dassel, Germany) and washed once with $10 \times$ SSPE. Filters were then dried at room temperature and baked at $80^{\circ}$ in a vacuum oven. The pUC9-cDNA hydrolases plasmids (Dakka et al. 1988; Wicker et al. 1988) were further labelled with $\left[\alpha^{32} \mathrm{P}\right] \mathrm{dCTP}$, using the Appligène random-priming kit, and finally hybridized at 107 counts/min per $\mathrm{ml}$ hybridization buffer. The pre-hybridization, hybridization and washing conditions were those described by Mueckler et al. (1983). After drying the filters at room temperature and autoradiographing them for 24-48 $\mathrm{h}$, individual spots were cut out and their radioactivity was measured by scintillation spectrometry using a Beckman LS 1800 spectrometer (Beckman, Palo Alto, CA, USA).

\section{Statistical analysis}

Statistical analysis was performed using ANOVA followed by Dunnett multiple comparison test (Zar, 1984). The values are expressed as means with their standard errors (five or fifteen animals per group) and all statistical analyses were considered to be significant at the $P<0.05$ level.

\section{RESULTS}

\section{Effect of dietary protein on the mRNA encoding serine proteases and some other hydrolases}

The hybridization specificity of the mRNA with the corresponding cDNA probes was first assessed by performing Northern-blot analysis. The electrophoretically-separated mRNA were identified as single bands, the migration of which corresponded to those of chymotrypsinogen, trypsinogen, elastase, procarboxypeptidase B, amylase and lipase (Fig. 1). The levels of specific mRNA coding for pancreatic hydrolases were determined by Northern-blot and by performing dot-blot hybridization with the corresponding cDNA probes. Representative autoradiography patterns are shown in Fig. 2 . The total RNA was extracted either immediately or 3 and $6 \mathrm{~h}$ after the actinomycin D injection from each pancreatic tissue of the rats fed on either the standard diet or one of the two experimental diets for $10 \mathrm{~d}$, and electrophoretically separated on $1.2 \%$ agarose 


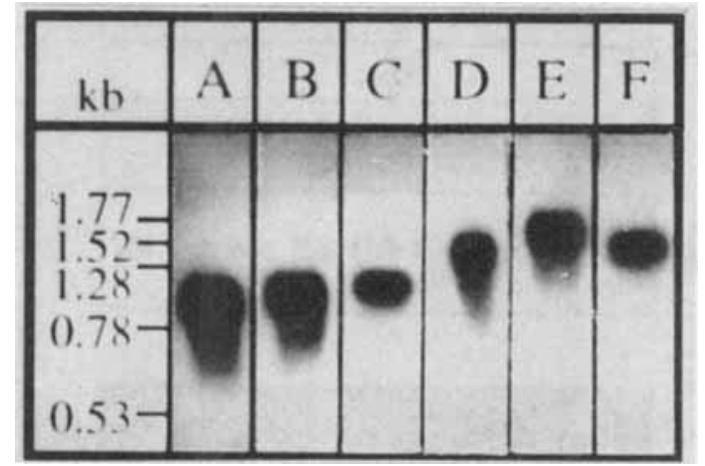

Fig. 1. Northem-blot analysis of pancreatic digestive enzyme mRNA. Total cellular pancreatic RNA (10 $\mu \mathrm{g})$ was extracted, denatured, separated on a $1.2 \%$ agarose-formaldehyde gel, transferred onto a nylon membrane and hybridized with cDNA of chymotrypsinogen (A), trypsinogen I (B), elastase I (EC 3.4.21.36; C), procarboxypeptidase B (D), amlyase $(E C$ 3.2.1.1; E) and lipase $(E C 3.1 .1 .3 ; \mathrm{F})$. Values shown are the molecular size (kilobases; kb) as determined by a parallel RNA ladder.

gel, transferred to nylon membrane, as well as spotted onto nitrocellulose in eight sequential dilutions. The levels of the specific mRNA encoding serine proteases and those of some other hydrolases were estimated by cutting out the radioactive spots and counting them. By normalizing the pancreatic levels of each specific mRNA to those obtained in the control rats fed on the standard diet containing $230 \mathrm{~g}$ casein $/ \mathrm{kg}$, it was possible, therefore, to estimate the relative level of specific mRNA present in the total cellular RNA isolated from each pancreatic gland. The quantitative results obtained at zero time (immediately after actinomycin D injection) with respect to the levels of the mRNA coding for the serine proteases chymotrypsinogen, anionic trypsinogen I and elastase I, as well as for other hydrolases such as amylase, lipase and procarboxypeptidase B, are shown in Fig. 3.

After ingestion of the high-protein diet, a significant increase in the level of the serine protease mRNA was observed. The enhancement of chymotrypsinogen mRNA was more pronounced $(90 \%)$ after $10 \mathrm{~d}$ of dietary intake than that of anionic trypsinogen I $(20 \%)$ and proelastase I $(40 \%)$. The levels of the specific mRNA coding for lipase and procarboxypeptidase B were not significantly affected by the increase in protein diet, whereas a decrease $(15 \%)$ in the amylase mRNA was observed. After $10 \mathrm{~d}$ of ingestion of the protein-free diet (no casein), an increase in the level of some serine protease mRNA was observed, and the enhancement of the mRNA coding for chymotrypsinogen was even more pronounced $(190 \%)$ in comparison with that of anionic trypsinogen I $(60 \%)$, while the mRNA level of elastase I remained unchanged. As regards the mRNA encoding other hydrolases under the protein-free dietary conditions, a $30 \%$ increase in amylase mRNA, a $20 \%$ increase in that of lipase and a $40 \%$ increase in that of procarboxypeptidase $\mathrm{B}$ were observed.

\section{Determination of half-life of specific mRNA coding for serine proteases and other pancreatic hydrolases in response to dietary protein content}

Each species of mRNA is degraded at a characteristic rate, which can be described by the first-order rate-constant $k_{d}((\ln 2) /$ half-life; Hargrove et al. 1990). Each rate-constant has a fixed value under steady-state conditions, but increases or decreases to a new value as the result of transcriptional activation or other regulatory events. A straightforward estimate 


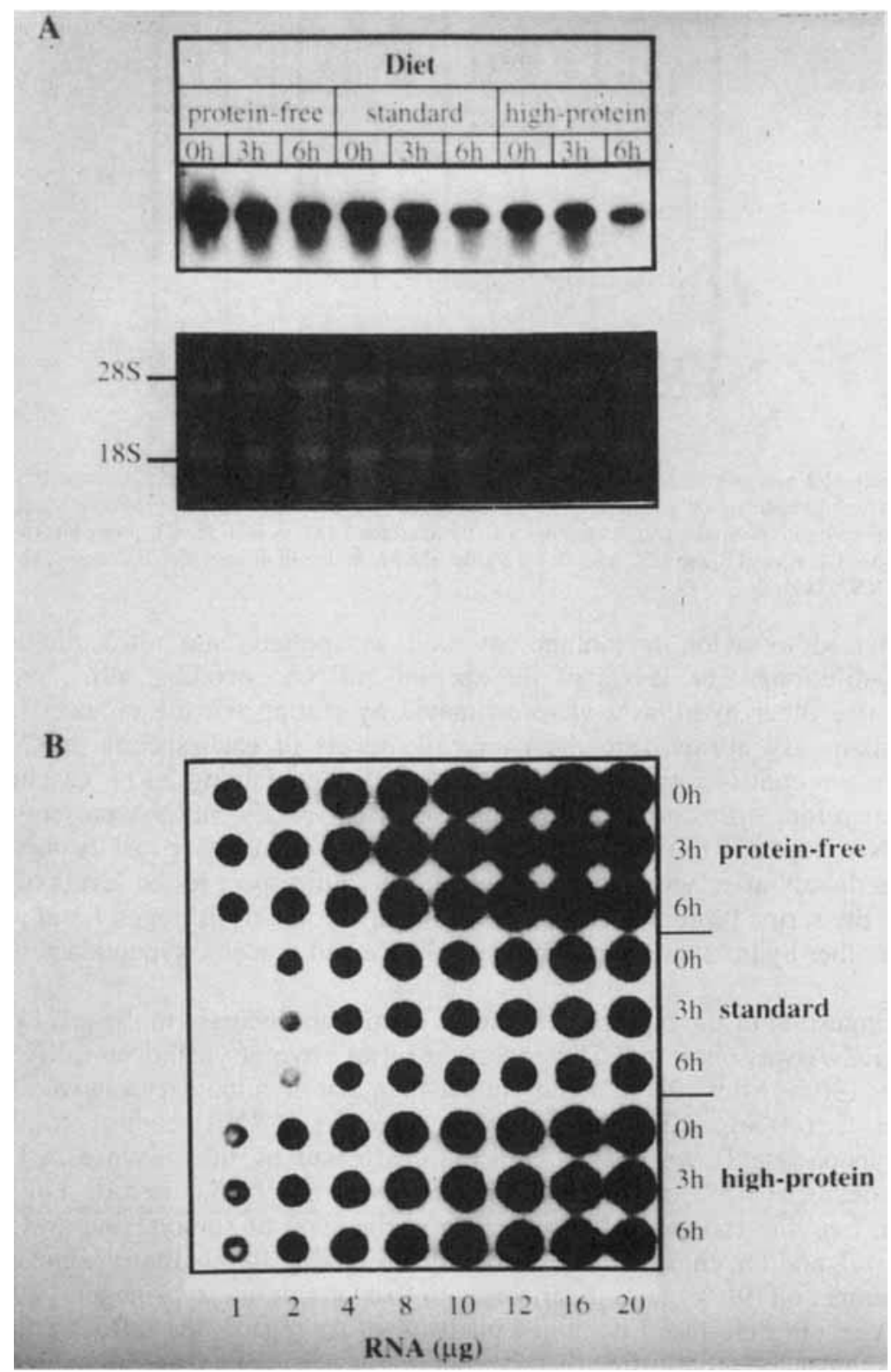

Fig. 2. Autoradiography pattern of a single Northern-blot analysis and dot-blot hybridization experiment with procarboxypeptidase B (A) and chymotrypsinogen (B) cDNA probes. (A), Total pancreatic RNA was prepared from three individuals on each diet immediately $(0 \mathrm{~h})$, or 3 and $6 \mathrm{~h}$ after actinomycin D injection. RNA was analysed by Northem blotting and hybridization with a procarboxypeptidase $B$ cDNA probe. Each line represents one individual. RNA quality and concentration are indicated by ethidium bromide stained gel at bottom. (B), Total pancreatic RNA (1$20 \mu \mathrm{g}$ ) isolated from rats fed on the protein-free diet, the standard diet and the high-protein diet for $10 \mathrm{~d}$ was denatured, spotted in eight sequential dilutions onto nitrocellulose and hybridized with ${ }^{32} \mathrm{P}$-labelled specific chymotrypsinogen cDNA probe. Rats were killed immediately $(0 \mathrm{~h})$ or 3 and $6 \mathrm{~h}$ after actinomycin D injection. 

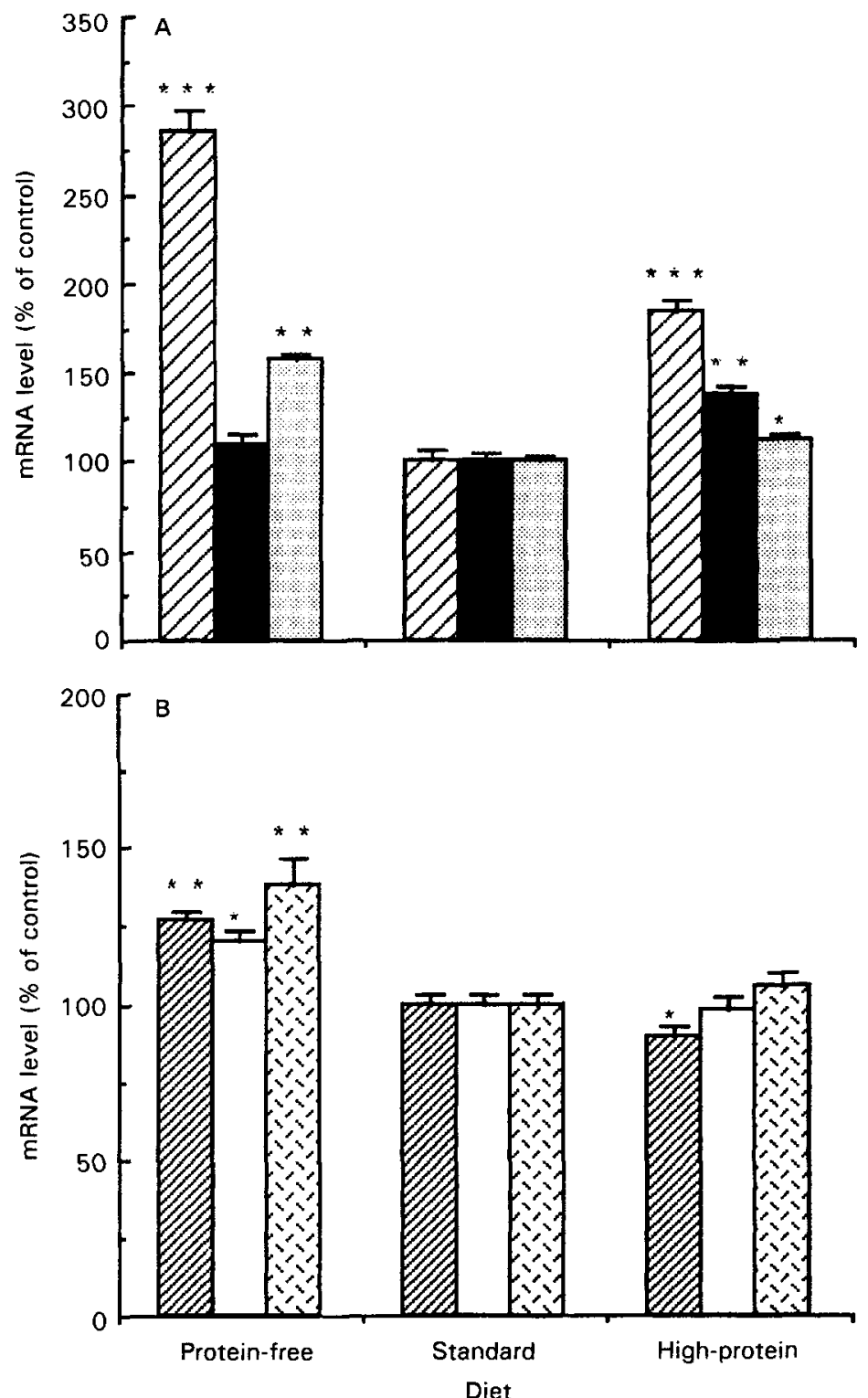

Fig. 3. Relative levels at time zero of the specific mRNA coding for some hydrolases in response to the changes in protein content of the diet. Specific mRNA encoding (A) chymotrypsinogen (Z), anionic trypsinogen I ( $\square$ ), elastase I $(E C$ 3.4.21.36; and (B) those encoding amylase $(E C$ 3.2.1.1; $)$, lipase $(E C$ 3.1.1.3; $\square$ ) and procarboxypeptidase B (R) were estimated by cutting out the radioactive spots from dot-blot hybridization patterns and counting them. Five typical hybridization lines were obtained by linear regression and, from the slope of each line, the amount of each specific mRNA present among the total RNA was calculated. The cytoplasmic mRNA contents were expressed as percentages of those in the pancreas of control rats fed on the standard diet. Results are means with their standard errors represented by vertical bars for five animals. $* P<0.05, * * P<0.01, * * P<0.001$. 
can be made by plotting $\Delta \mathrm{C} / \Delta \mathrm{t} v . \mathrm{C}$, where $\Delta \mathrm{C}$ is the change in a specific mRNA concentration during an interval $\Delta \mathrm{t}(6 \mathrm{~h})$ and $\mathrm{C}$ is the specific mRNA concentration at the midpoint $\left(3 \mathrm{~h}\right.$ ) of each interval (Engler et al. 1973). The $k_{d}$ value can be derived from the slope $\left(-k_{d}\right)$ of each straight line obtained (data not shown).

The estimates of the pancreatic mRNA half-lives under the different dietary conditions, obtained using the equation half-life $=(\ln 2) / k_{d}$, are given in Table 2 . The values obtained under the standard diet ranged between $10 \mathrm{~h}$ and $17 \mathrm{~h}$, yielding an average half-life (10-20 h) of the mRNA turnover in eukaryotic cells corresponding to two kinetic populations, the one relatively unstable and other stable (Hargrove \& Schmidt, 1989). Based on the half-lives of pancreatic hydrolase mRNA, two groups are significantly different; the one more stable, including mRNA coding for anionic trypsinogen I, proelastase I and amylase, with mRNA half-lives ranging between $14 \mathrm{~h}$ and $19 \mathrm{~h}$, and the other one, including mRNA encoding procarboxypeptidase $B$, chymotrypsinogen and lipase, with mRNA half-lives ranging between $10 \mathrm{~h}$ and $13 \mathrm{~h}$. Any changes in the dietary protein content resulted in changes in some of the pancreatic hydrolase mRNA half-lives. Most of hydrolase mRNA were characterized by the fact that their half-lives showed no change when the animals were fed on the high-protein diet instead of the standard diet, except in the case of the mRNA coding for anionic trypsinogen I, which increased about $30 \%$ and that of proelastase I, which decreased by about $56 \%$, which suggested that the dietary control of the biosynthesis of these two proteins may involve the regulation of mRNA stability. When rats were fed on the protein-free diet, all mRNA half-lives were affected except that of lipase. The half-lives of serine protease (anionic trypsinogen I, chymotrypsinogen) and procarboxypeptidase B mRNA increased about 70, 170 and $80 \%$ respectively, whereas the half-lives of the mRNA coding for amylase and proelastase I decreased by about 65 and $57 \%$ respectively, in comparison with the control animals. These results suggested that the regulation of expression of most of the mRNA coding for pancreatic hydrolases which occurred when rats were fed on a protein-free diet may have involved changes in the mRNA stability during the animals' nutritional adaptation.

Table 2. Half-life determination of some specific mRNA coding for pancreatic hydrolases in response to standard, protein-free and high-protein diet intake in rats*

(Each specific mRNA half-life was determined as (ln 2) $/ k_{d}$, in which $k_{d}$ is the specific degradation constant corresponding to each mRNA. Values were expressed as means with their standard errors for fifteen animals)

\begin{tabular}{|c|c|c|c|c|c|c|}
\hline \multirow{3}{*}{$\begin{array}{l}\text { Diet... } \\
\text { mRNA }\end{array}$} & \multicolumn{6}{|c|}{ Half-life (h) } \\
\hline & \multicolumn{2}{|c|}{ Standard } & \multicolumn{2}{|c|}{ Protein-free } & \multicolumn{2}{|c|}{ High-protein } \\
\hline & Mean & SEM & Mean & SEM & Mean & SEM \\
\hline Amylase (EC 3.2.1.1) & $17 \cdot 3^{a}$ & 1.4 & $6 \cdot 1^{\mathrm{c}}$ & $0 \cdot 3$ & $20 \cdot 4^{a}$ & 6.4 \\
\hline Proelastase I & $15 \cdot 9^{\mathrm{a}}$ & $2 \cdot 2$ & $6 \cdot 8^{\mathrm{c}}$ & 0.5 & $7 \cdot 0^{c}$ & 0.5 \\
\hline Trypsinogen I & $15 \cdot 6^{\mathrm{a}}$ & 1.4 & $26 \cdot 2^{\mathrm{d}}$ & $4 \cdot 0$ & $19 \cdot 7^{d}$ & $2 \cdot 1$ \\
\hline Chymotrypsinogen & $12 \cdot 0^{\mathrm{b}}$ & 1.4 & $31.8^{d}$ & $3 \cdot 6$ & $13 \cdot 2^{b}$ & $1 \cdot 1$ \\
\hline Lipase (EC 3.1.1.3) & $11.8^{b}$ & 0.9 & $10 \cdot 0^{\mathrm{b}}$ & $1 \cdot 1$ & $13 \cdot 4^{\mathrm{b}}$ & $2 \cdot 8$ \\
\hline Procarboxypeptidase B & $10 \cdot 7^{b}$ & 0.8 & $19.7^{d}$ & $1 \cdot 1$ & $10 \cdot 8^{b}$ & 0.7 \\
\hline
\end{tabular}

a,b,c,d Mean values in the same row with unlike superscript letters were significantly different $(P<0.05)$.

* For details of diets and procedures, see Table 1 and pp. 834-836. 


\section{DISCUSSION}

The present study focused on the pancreatic mRNA stability recorded in rats fed on diets differing in their protein content. For this purpose, the mRNA synthesis was blocked by intraperitoneally injecting a high but sub-lethal dose of actinomycin $\mathrm{D}$ into the rats. Actinomycin D, an inhibitor of the DNA-dependent RNA synthesis (Reich, 1963), is known to bind DNA, thus modifying its structure and consequently impairing its template function. The use of this antibiotic as a biochemical tool for estimating mRNA stability has, however, some limitations. Transcription inhibitors such as actinomycin D or 5,6 dichloro-1-D-ribofuranosylbenzimidazole may themselves influence the rate of $\mathrm{mRNA}$ degradation or stimulate the function of adrenal cortex, and even have a high degree of toxicity, as well as inducing maximal inhibition of RNA synthesis for rather short periods. The use of pulse-chase procedures to estimate mRNA stability is greatly complicated by the efficient re-utilization made of nucleotides from the degraded RNA in RNA synthesis. Meanwhile, comparable results have been obtained on phosphoenol pyruvate carboxykinase mRNA stability with both procedures and on tyrosine hydroxylase mRNA stability using actinomycin D and 5,6 dichloro-1-D-ribofuranosylbenzimidazole as transcription inhibitors as well as by performing pulse-chase experiments using 4-thiouridine (Czyzykkrzeska et al. 1994). Intraperitoneally injecting actinomycin D (2 mg/ $\mathrm{kg}$ body weight) into the rat completely inhibited the nuclear synthesis for at least $6 \mathrm{~h}$ (Pitot et al. 1965). The subsequent degradation of pancreatic mRNA was then assessed by directly estimating the levels of the mRNA extracted from each gland after actinomycin $D$ injection $(0,3$ and $6 \mathrm{~h})$ by performing Northern blot and dot-blot hybridization with specific cDNA probes.

As shown in the present study, determination of the rate of decay of mRNA after intraperitoneally injecting actinomycin $\mathrm{D}$ into rats fed on the standard diet $(230 \mathrm{~g}$ casein $/ \mathrm{kg}$ ) yielded calculated half-lives ranging between $10 \mathrm{~h}$ and $17 \mathrm{~h}$ for most pancreatic mRNA, which were quite consistent with the average half-lives $(10-20 \mathrm{~h})$ found for eukaryotic mRNA (Hargrove \& Schmidt, 1989). The stability of the active mRNA coding for chymotrypsinogen, amylase, lipase and procarboxypeptidase B were not affected by the dietary manipulations when the rats were fed on a high-protein diet. Any increase in the level of the chymotrypsinogen mRNA or any decrease in the level of the amylase mRNA observed under this nutritional condition, therefore, can probably have resulted only from an enhanced or inhibited transcription of the corresponding genes, since we previously established that dietary regulation of the synthesis of serine protease zymogens and amylase in the rat does not involve any control at the translational level (Wicker et al. 1983, 1984). The mRNA half-lives of anionic trypsinogen I and proelastase I were found, on the contrary, to change in response to a high-protein diet. Interestingly, the anionic trypsinogen mRNA half-life increased, whereas that of proelastase I decreased. The observed enhancement of mRNA stability in the former case may be high enough to account for the overall increase in anionic trypsinogen observed in the animals fed on the high-protein diet. Conversely, the decrease in the stability of the mRNA coding for proelastase I does not explain the observed effects of the high-protein diet on this enzyme. The nutritional regulation of the proelastase I gene, therefore, must involve a control at some other level.

Contrary to what was observed in the case of the high-protein diet, when the rats were fed on the protein-free diet all the pancreatic mRNA stabilities were affected, except that of the lipase mRNA, which suggests that the increase observed in the level of the latter under this nutritional condition may have resulted only from an enhanced transcription of its gene. The enhancement of the serine protease chymotrypsinogen and anionic trypsinogen I 
mRNA levels observed here in response to a protein-free diet may well have resulted from an enhancement of their mRNA stability, possibly associated with a slight enhancement of their gene transcription, as occurs with procarboxypeptidase B. As observed with the highprotein diet, the stability of the proelastase I mRNA, decreased, although its level was not affected after ingestion of the protein-free diet, which suggests that another control of gene expression distinct from transcription may have been involved, such as the translational one (Dakka et al. 1990). With respect to amylase, no correlation between its mRNA level, which increased weakly, and its stability, which decreased sharply after ingestion of the protein-free diet, was obtained, suggesting the existence of different levels of regulation. All these results might explain previous findings about the biosynthesis of pancreatic enzymes in response to a high-carbohydrate protein-free diet that was regulated in reverse proportion to the corresponding nutritional substrates (Dakka et al. 1988). The response of the pancreas to the diet might depend on the stability of the respective mRNA.

The molecular mechanism whereby mRNA stability is affected by dietary manipulation is still unknown. The stability of eukaryotic mRNA is variable, both from one cell to another and from one mRNA to another. Some mRNA known to have short half-lives include those encoding many inducible enzymes which are regulated from the point of view of their stability as well as their transcription rate. The stability changes are responsible for a large proportion of the increase in the mRNA concentration observed after adding the inducer (Austin \& Kay, 1982). The authors have proposed two possible explanations for the specific stabilization of cellular RNA. One is that the nuclear synthesis and processing of an mRNA whose stability is regulated may be accompanied by covalent modifications that render the mRNA resistant to degradation. In the presence of an effector, these modifications might be reversed in the cytoplasm, altering the stability of the mRNA. The other hypothesis is that mRNA stability may be regulated via reversible proteinnucleic acid interactions in the cytoplasm, involving the $3^{\prime}$ untranslated region ( $3^{\prime} \mathrm{UTR}$ ). Similar events may have occurred during pancreatic nutritional adaptation, when the mRNA stability was increased by the nature of the diet. Direct or indirect effects via hormones may have induced $3^{\prime} \mathrm{UTR}$-binding proteins that may have stabilized some pancreatic mRNA.

In conclusion, the results presented here indicate that mRNA stability may depend on nutritional conditions. Although the present data obtained during pancreatic adaptation might be explained in terms of changes in the mRNA stability, we must now focus our efforts on understanding the molecular events underlying this phenomenon.

The authors wish to thank Professor Maurice Roux, Biomathematics Laboratory at the University of Aix-Marseille III, for his help in statistical analysis.

\section{REFERENCES}

Austin, S. A. \& Kay, J. E. (1982). Translational regulation of protein synthesis in eucaryotes. Essays in Biochemistry 18, 80-109.

Behrman, H. R. \& Kare, M. R. (1969). Adaptation of canine pancreatic enzymes to diet composition. Journal of Physiology 205, 667-676.

Ben Abdeljlil, A. \& Desnuelle, P. (1964). Sur l'adaptation des enzymes exocrines du pancréas à la composition du régime (On the adaptation of pancreatic exocrine enzymes to diet composition). Biochimica et Biophysica Acta 81, 136-149.

Bonini, J. A. \& Hofmann, C. (1991). A rapid, accurate, nonradioactive method for quantitating RNA on agarose gels. Biotechniques 11, 708-710. 
Chomczynski, P. \& Sacchi, N. (1987). Single step method of RNA isolation by acid guanidinium thiocyanatephenol-chloroform extraction. Analytical Biochemistry 162, 156-159.

Czyzykkrzeska, M. F., Furnari, B. A., Lawson, E. E. \& Millhorn, D. E. (1994). Hypoxia increases rate of transcription and stability of tyrosine hydroxylase messenger RNA in Pheochromocytoma. Journal of Biological Chemistry 269, 760-764.

Dagorn, J.-C. \& Lahaie, R. G. (1981). Dietary regulation of pancreatic protein synthesis. I. Rapid specific modulation of enzyme synthesis by changes in dietary composition. Biochimica et Biophysica Acta 654, 111118.

Dakka, N., Puigserver, A. \& Wicker, C. (1990). Regulation by a protein-free carbohydrate-rich diet of rat pancreatic mRNAs encoding trypsin and elastase isozymes. Biochemical Journal 268, 471-474.

Dakka, N., Wicker, C. \& Puigserver, A. (1988). Specific response of serine protease mRNA to a protein-free diet in the rat pancreas. European Journal of Biochemistry 174, 231-236.

Engler, E. M., Andose, J. D. \& von R. Schleyer, P. (1973). Critical evaluation of molecular mechanics. Journal of American Chemical Society $95,8005-8025$.

Gidez, L. I. (1973). Effect of dietary fat on pancreatic lipase levels in the rat. Joumal of Lipid Research 14, 169177.

Giorgi, D., Renaud, W., Bernard, J. P. \& Dagorn, J.-C. (1985). Regulation of proteolytic enzyme activities and mRNA concentrations in rat pancreas by food content. Biochemical and Biophysical Research Communications 127, 337-342.

Grossman, M. I., Greengard, H. \& Ivy, A. C. (1943). The effect of dietary composition on pancreatic enzymes. American Journal of Physiology 138, 676-682.

Hargrove, J. L., Hulsey, M. G., Schmidt, F. H. \& Beale, E. G. (1990). A computer program for modeling the kinetics of gene expression. Biotechniques 8, 652-654.

Hargrove, J. L. \& Schmidt, F. H. (1989). The role of mRNA and protein stability in gene expression. FASEB Journal 3, 2360-2370.

Mueckler, M. M., Merrill, M. J. \& Pitot, H. C. (1983). Translational and pretranslational control of ornithine aminotransferase synthesis in rat liver. Journal of Biological Chemistry 258, 6109-6114.

Pitot, H. C., Peraino, C., Lamar, C. \& Kennan, A. L. (1965). Template stability of some enzymes in rat liver and hepatoma. Proceedings of the National Academy of Sciences USA 54, 845-851.

Reboud, J. P., Ben Abdeljlil, A. \& Desnuelle, P. (1962). Variation de la teneur en enzymes du pancréas de rat en fonction de la composition des régimes (Dietary modulation of enzyme levels in the rat pancreas). Biochimica et Biophysica Acta 58, 326-337.

Reboud, J. P., Marchis-Mouren, G., Paséro, L., Cozzone, A. \& Desnuelle, P. (1966). Adaptation de la vitesse de biosynthèse de l'amylase pancréatique et du chymotrypsinogène à des régimes riches en amidon ou en protéines (Adaptation of pancreatic amylase and chymotrypsinogen rates of biosynthesis to high-protein diets or high-carbohydrate diets). Biochimica et Biophysica Acta 117, 351-367.

Reich, E. (1963). Biochemistry of actinomycins. Cancer Research 23, 1428-1441.

Sambrook, J., Fritsch, E. F. \& Maniatis, T. (1989). Molecular Cloning, A Laboratory Manual, 2nd ed. Cold Spring Harbor, NY: Cold Spring Harbor Laboratory.

Scheele, G. A. (1986). Regulation of the gene expression in the exocrine pancreas. In The Exocrine Pancreas: Biology, Pathology and Diseases, pp. 55-68. [V. L. W. Go, editor]. New York: Raven Press.

Schick, J., Verspohl, R., Kern, H. \& Scheele, G. (1984). Two distinct adaptative responses in the synthesis of exocrine pancreatic enzymes to inverse changes in protein and carbohydrate in the diet. American Journal of Physiology 247, G611-G616.

Wicker, C. \& Puigserver, A. (1987). Effects of inverse changes in dietary lipid and carbohydrate on the synthesis of some pancreatic secretory proteins. European Journal of Biochemistry 162, 25-30.

Wicker, C., Puigserver, A. \& Scheele, G. A. (1984). Dietary regulation of levels of active mRNA coding for amylase and serine protease zymogens in the rat pancreas. European Journal of Biochemistry 139, 381-387.

Wicker, C., Scheele, G. A. \& Puigserver, A. (1983). Adaptation au régime alimentaire du niveau des ARNm codant pour l'amylase et les protéases à sérine pancréatiques chez le rat (Dietary adaptation of the levels of mRNA encoding pancreatic amylase and serine proteases in the rat). Compte Rendu Académie des Sciences Paris 297, 281-285.

Wicker, C., Scheele, G. A. \& Puigserver, A. (1988). Pancreatic adaptation to dietary lipids is mediated by changes in lipase mRNA. Biochimie 70, 1277-1283.

Zar, J. H. (1984). Biostatistical Analysis, pp. 718-720. Englewood Cliffs: Prentice Hall. 